\title{
Obituaries
}

\section{Kurt Semm}

A pioneer in minimally invasive surgery

On 13 September 1980 gynaecologist Professor Kurt Semm performed the world's first laparoscopic appendicectomy at the University of Kiel in Germany. When Semm, director of the department of obstetrics and gynaecology at Kiel University Hospital, later told a surgical meeting what he had done, the president of the German Surgical Society called for his suspension.

Semm was a pioneer in minimally invasive surgery who was initially ridiculed and attacked by many of his colleagues but later was praised for his early advances in a field that went on to become highly fashionable. Nowadays minimally invasive surgery is a scientifically established standard procedure for certain operations.

After qualifying in 1951, Semm made his first scientific contributions in gynaecological endocrinology under Nobel prize winner Adolf Butenandt in Munich. For the next few years his work concentrated on the treatment of infertility.

In the early 1960s he started to dedicate his scientific life to laparoscopic surgery, because as a trained toolmaker and physician he had recognised its enormous potential. His technical skills enabled him to make several inventions-for instance, the first electronic insufflator for carbon dioxide, as well as a uterine manipulator, a tubal patency testing device, and several surgical instruments for the fine art of minimally invasive operations.

The first publications on diagnostic laparoscopy came from the American surgeon Raoul Palmer. At the time, diagnostic laparoscopies were well accepted, but

\section{John O’Donel Alexander}

Former consultant dermatologist Glasgow Royal Infirmary (b Cork 1915; q Birmingham 1938; FRCP Glas), died from cancer on 5 May 2003. Jack Alexander was briefly a general practitioner in Birmingham, served in the Royal Army Medical Corps in the Middle East during the second world war, and came home to be a GP and farmer in Donegal. When that proved unsatisfactory he left to train in dermatology at the Glasgow Royal Infirmary, and spent the rest of his working life there. His important book Arthropods and

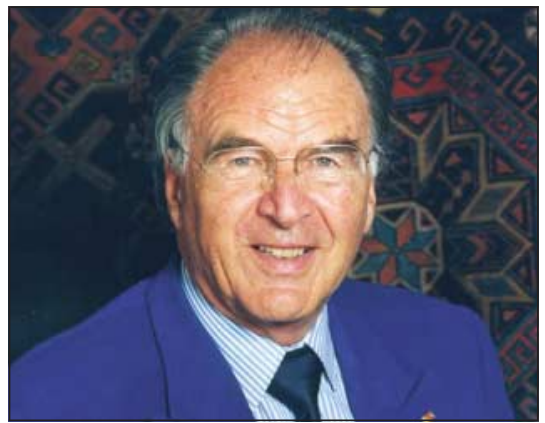

attention to Semm's nonsense. The scepticism was not just confined to Germany. When Semm tried to publish his paper on the first laparoscopic appendicectomy it was rejected because the technique reported was assumed to be unethical.

Yet during the 1970s the University of Kiel became one of the world's leading centres of minimally invasive gynaecological surgery. Semm established several standard operations that were regularly performed. These included ovarian cyst enucleation, myomectomy, treatment of ectopic pregnancy, and, finally, hysterectomy.

In the 1980s, after Semm's tireless and surgical attempts-apart from gynaecological sterilisation-were considered experimental and therefore unethical. It seemed unthinkable that surgeons should not have a good view of the entire operation site or have direct access and manual contact with the organs that they wished to treat, even if Semm's method might mean smaller incisions and reduced tissue damage. When Semm tried to convince his colleagues from other surgical disciplines in Kiel and elsewhere of the advantages of laparoscopic surgery-for instance, for gall bladder removal-they were mostly sceptical or apprehensive. Some of his co-workers asked him to have a brain scan, suspecting brain damage or a brain disease in someone who would attempt such an extraordinarily dangerous procedure.

When Semm presented the enucleation of an ovarian cyst by laparoscopy in 1972, a famous gynaecologist commented that any young doctor who wished to advance in the German academic world should not pay any

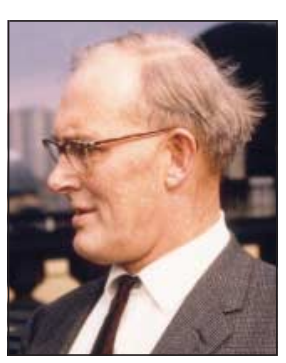

the Skin celebrated his interest in entomology. Predeceased by his wife, Isobel, and his persistent travelling and lecturing, laparoscopy started to spread in the medical world and advanced from a diagnostic to a surgical procedure, firstly in the United States and later in other parts of Europe. This development was also helped by the publication of Semm's standard books on operative and endoscopic surgery in many languages, as well as his many teaching films. Recognising that the successful introduction of minimally invasive techniques largely depended on the excellence of surgical training, in 1985 Semm constructed a training device, the "pelvi-trainer," which has been used on both sides of the Atlantic.

He leaves a wife, Iseult O'Neill, and two children. [AnNette Tuffs]

Kurt Karl Stephan Semm, former director department of obstetrics and gynaecology Kiel University Hospital, Germany (b Munich 1927. $q$ Munich 1951), died in Tucson, Arizona, United States, on 16 July 2003.

son, he leaves a daughter and his grandchildren. [Alan Lyell]

\section{Harold Leslie Caplan}

Consultant in child and adolescent psychiatry St George's, University College, and Florence

Nightingale Hospitals, London (b Melbourne, Australia, 1938; q Melbourne 1960; MPhil, FRACP, FRCPsych), died from malignant glioma on June 72003.

Torn between medicine and literature, Harold Caplan read both with distinction, 


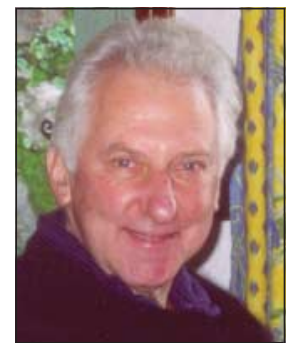

graduating MB BS in 1960 and BA with a major in English Literature in 1966. Psychiatry offered the perfect hybrid between medicine and literature. The most important of his several seminal contributions to psychiatry were his landmark prospective studies on the effect of maternal postnatal depression on the cognitive and emotional development of the child. He leaves his first wife, Betty (marriage dissolved in the 1980s); their two daughters; and his second wife, Wendel. [GEORGE FINK]

\section{Desmond Michael Devane}

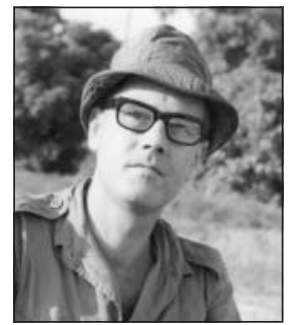

Former general practitioner York (b Gillingham, Kent, 1926; q Guy's Hospital, London, 1951; DPH, DTME'H), died from multi-infarct dementia on 20 March 2003.

Following a career in the army, serving in Malaysia, Aden, and Singapore, and reaching the rank of lieutenant colonel, Desmond Devane became a family doctor in York from 1968 until his retirement in 1988. His main passion was golf, throughout both his working life and in retirement until his final illness robbed him of this enjoyment. He leaves a wife, Isobel; three children; and six grandchildren. [Michael Devane]

\section{Andrea Menessy}

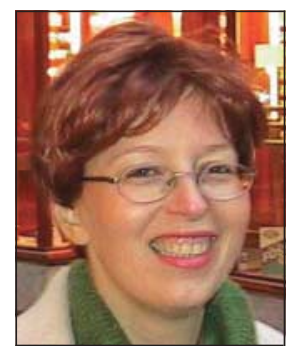

Clinical pharmacologist (b Romania 1969; q Freiburg, Germany, 1995; MD, MRCP), died from cervical cancer on 28 June 2003.
After medical school in Romania and Germany, Andrea took up junior house jobs in the United Kingdom and afterwards joined a medical rotation in Cheltenham. She took several months off to travel around the world with her future husband. Once back in England, after further six months as a senior house officer in emergency medicine, she entered a career in clinical pharmacology. Travelling was her passion. She leaves a husband, James. [AnNe HofFMANN]

\section{Desmond Alan Dill \\ Montgomery}

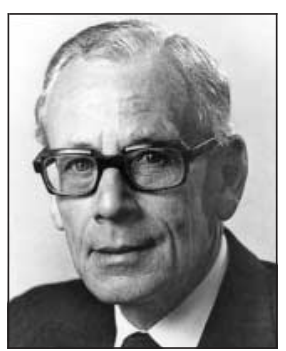

Former consultant physician Royal Victoria Hospital, Belfast, and honorary professor of endocrinology, Queen's University, Belfast ( $b$ China 1916; q Belfast 1940; CBE, MD, FRCP), d 7 July 2003.

He had an unusual wartime introduction to medicine as an administrative army doctor in Lucknow, where he was responsible for the reception and redirection of trainloads of sick and injured soldiers evacuated from Burma in 1942. After training posts in London he was appointed consultant physician to the Royal Victoria Hospital, Belfast, in 1951. He was the first clinical endocrinologist, and subsequently developed an extensive cross-disciplinary team at the Sir George E Clarke Metabolic Unit for diabetes and endocrinology. He was co-founder in 1960 of the Corrigan Club, a cross-border visiting club with the object of promoting friendship among physicians in Ireland. He leaves a wife, Susan, and two children. [Richard Clarke, David Hadden]

\section{Simon Smullen}

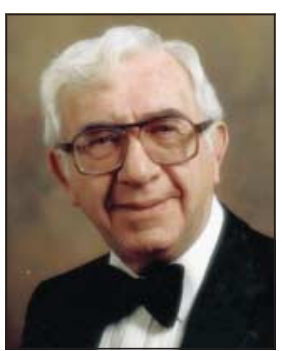

Former general practitioner Glasgow (b Dublin 1916; q Dublin 1942; MA, MD), d 24 July 2003. With a view to entering the Rabbinate Simon Smullen took a degree in Semitic languages before changing to medicine. Like so many of his contemporaries he left Dublin on graduation to pursue his career in Britain, firstly in Leeds and then in Glasgow. He took a paediatric clinic at Yorkhill Hospital and in 1951 gained his MA, MD for his thesis on rheumatic heart disease in young children. He then worked as a family doctor for more than 40 years in the Govanhill area of Glasgow. He was always charitable to many home and Israeli causes. Predeceased by his first wife, Fay Links, he leaves his second wife, Sylvia Gillis Florence, his children, and many grandchildren. [Claire Stone]

\section{Peter Wright}

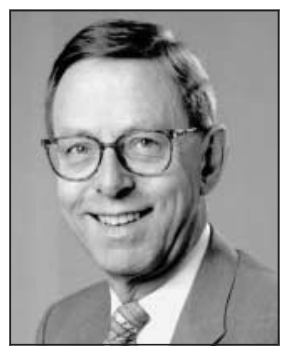

Former consultant ophthalmologist Moorfields Eye Hospital and King's College Hospital, London, and past president of the Royal College of Ophthalmologists (b London 1932; $q$ London 1955; FRCP, FRCS, FRCOphth), died from complications of myeloid leukaemia on 26 May 2003.

After training at Moorfields and a senior registrar and consultant post at King's, in 1978 he became a full time consultant at Moorfields and the Institute of Ophthalmology. He was responsible for the external disease service dealing with infection and inflammation in the anterior part of the eye. It was during his presidency that the College of Ophthalmologists was granted a royal licence. In 1993 Peter retired and moved to Devon, where he had time to enjoy his major interest, classical music. He played the piano seriously. Predeceased by his son, who was killed in the Lockerbie crash, he leaves his partner, John Morris, two daughters, and two granddaughters. His marriage was dissolved in 1992. [Peter Wright, MARGARet HallendorfF]

\section{Gerald Charles Joseph Bennett}

There will be a meeting to celebrate the life and work of Professor Gerry Bennett (obituary BMJ 2003;326:1270) on 21 September 2003 in the Great Hall of the People's Palace, Queen Mary University of London, Mile End, London E1 4NS. Anyone wishing to attend should apply for tickets to Josie Dance at J.Dance@qmul.ac.uk

Longer versions of these obituaries are available on bmj.com 